\title{
US UNCONVENTIONAL MONETARY POLICY AND ITS IMPACT ON US INCOME
}

\author{
Deergha Raj Adhikari, University of Louisiana at Lafayette, Lafayette, LA, U.S.A.
}

\author{
dx.doi.org/10.18374/JABE-21-2.2
}

\begin{abstract}
Starting in November 2008 and until October 2014, the Fed used the policy of quantitative easing to increase the amount of non-borrowed reserves in the banking system with an objective to lowering the bank lending rate, thereby raising the aggregate demand and ultimately boosting the US GDP. In this paper, therefore, we investigate the impact of Fed's such policy on US GDP. So, our model variables are US GDP (GDP) and the quantity of non-borrowed reserves created by the Fed (NBR). We estimate a vector error correction model (VECM) on the data ranging from 1980 to 2012. Our study finds that, while the Fed's quantitative easing policy positively affect the US GDP in the short run, it has no impact in the long run.
\end{abstract}

Keywords: quantitative easing, non-borrowed reserves, aggregate demand, GDP, VECM, short-run impact, long-run impact, etc. 